\title{
Oryantalizm Ekseninde Sanat, Siyaset ve Din İlişkisi
}

\section{The Relationship Between Art, Politics and Religion in the Axis of Orientalism}

Lütfü Kaplanoğlu

Doç. Dr., Yıldız Teknik Üniversitesi, Sanat ve Tasarım Fakültesi, Sanat Bölümü

email: 1kaplanoglu@gmail.com (DORCID ID: https://orcid.org/0000-0002-7094-8302

\author{
$\underline{V}_{\text {for Authors }}^{\text {iThticeserchers }}$ " Bu makale bilimsel etik ve kurallara uygun hazırlanmış ve intihal incelemesinden geçirilmiştir. Etik kurul onayı \\ gerektirmemektedir.
}

Atıf (APA 6)/To cite this article

Kaplanoğlu, L. (2020). Oryantalizm ekseninde sanat, siyaset ve din ilişkisi. Atatürk Üniversitesi Güzel Sanatlar Enstitüsü Dergisi, 26(45), 722-729. doi: https://doi.org/10.35247/ataunigsed.792746

Makale Gönderim Tarihi/Received: 09/09/2020

Makale Kabul Tarihi/Accepted: 03/10/2020

Makale Yayın Tarihi/Published: 22/10/2020

Review Article/Derleme Makale

\section{Öz}

Türk sanat tarihi incelendiğinde özellikle geleneksel sanatlar olarak adlandırılan sanatların Oryantalizm etkisinde kaldığı anlaşılmaktadır. "İslam Sanatı” kavramı ve İslam'da resim yasağı söylemleri, "İslam Coğrafyası" olarak kabul edilen topraklardaki sanatçı ve sanat eserlerinin yok sayılması üzerine temellendirilmiștir.

Literatür taramalarında "geleneksel sanatlar" olarak yapılan tanımlamalar, sanatın yenilikçi, yaratıcı ve sürekli gelişim gösteren özelliğini ortadan kaldırmak üzere temellendirilip yazılı kaynaklara yerleştirilmiştir. Batılılarca "İslamic Art" yani İslami sanat, İslam etkili sanat olarak yazılan ama "İslam sanatı" olarak yerleștirilmiş kavram ekseninde tezhip, minyatür, ebru ve hat gibi sanatlar kutsanırken, bu sanatları icra eden sanatçılar bu tanımlama üzerinden özel statüye kavușup nemalanmıs ve bu tanımlamaya itiraz etmemişlerdir. Oryantalistler "Geleneksel Sanat", "İslam Sanatı" kavramını folklorik bir öğe olarak kabul edip tanımlamaktadır. Bu tanımlamaların etkisi bu sanatların gelişim çizgisini sosyal ve siyasi olarak negatife dönüştürmüştür. Hem Kur'an'a hem de sanatın ruhuna aykırı olarak kullanılan "İslam Sanatı" kavramı "dinin emrettiği bir sanat" varmış gibi ortaya konulmaktadır. Bu durum sanat ve genel sanat kuramları için çelişkili ve düşündürücü sonuçlar doğurmaktadır.

Hristiyanlığın özellikle ikinci yüzyılında başlayan ve özellikle 8 . ve 9. yüzyıllarında zirve yapan resim yasağına dair tartışmalar yapılmıştır. Müslüman toplulukları için de buna benzer tartışmalar söz konusudur. "Dinde resim veya suret yasağı vardır" ile başlayan cümlelerin İslam kitabı olan Kuran'a dayanmadığı bilinmekte iken; bu yasağın israiliyat olarak kabul edilen ve Yahudilikten İslam'a, Yahudilikten Hristiyanlığa geçenlerin Yahudilikten kalma inanışlarını kültür olarak bu dinlere taşıdığı bilinmemektedir.

Bu çalışmada oryantalizmin sanat terimleri üzerinden İslam coğrafyası üzerine etkisi incelenerek sanatta dine dayandırılan kavram problemleri olarak "İslam Sanatı" (din sanatı) kavramı dini boyutu, sanat boyutu, siyasi boyutu olmak üzere üç başlık altında incelenmiştir.

Anahtar Kelimeler: Sanat, İslam Sanatı, Hristiyanlık Sanatı, Resim Yasağı, Din, Minyatür, Resim

\begin{abstract}
A close look into the history of Turkish art reveals the influence of Orientalism, especially on so-called traditional art forms. The concept of "Islamic Art" and the discourse on the prohibition of painting in Islam are based on the fact that artists and art works on the "Islamic Geography" are generally ignored.

Literature review shows that "traditional art" forms are defined and put into written sources in a way that destroys the innovative, creative and constantly evolving character of art. The misinterpreted concept of "Islamic Art" as called by the Western world must rather mean art with the influence of Islam; however, it sanctifies certain art forms such as illuminated manuscript, miniature, paper marbling and calligraphy giving the artists in these branches of art a special status which has made them benefit from and make no objection to the said definition. Orientalists adopt and define the concepts of "Traditional Art" and "Islamic Art" as a folkloric element. The influence of these definitions has turned the development trend of these art forms downwards from social and political perspectives.
\end{abstract}

The concept of "Islamic Art", employed in a way that contradicts both Qur'an and the spirit of art, suggests that this art form is commanded by the religion. This brings along conflicting and challenging consequences pertaining to art and general theories of art.

The prohibition of painting in Christianity that started in the second century and peaked especially in the 8th and the 9th centuries has been an important discussion topic. Similar discussions occur within Muslim communities. It is widely known that propositions starting with "the religion prohibits painting or illustration" are not based on Qur'an, the holy book of Islam, whereas it is not of common knowledge that this prohibition was in fact carried over to Islam and Christianity by those who converted from Judaism taking their beliefs rooted in Judaism with them as a cultural element, which is defined as Isra'illiyat.

The aim of this study is to analyze the influence of orientalism on the Islamic geography through the terminology of art and to examine "Islamic Art" (religious art) as a part of religion-related conceptual problems in art, focusing on three main headings including religious, artistic and political dimensions of the issue.

Keywords: Art, İslam Art, Christian Art, Prohibition on Painting, Religion, Miniature, Paintin

\section{Giris}

Sanat, "insanlığın varlığından itibaren plastik, fonetik ya da ritmik dışavurumlardan her birini oluşturan bir ifade biçimi" olarak kendini gösterirken; siyaset, "devlet işlerini düzenleme ve yürütme sanatıyla ilgili özel görüş veya anlayış" şeklinde açıklanır ("Sanat" ve "siyaset", t.y.). Din ise "Tanrı'ya, doğaüstü güçlere, çeşitli kutsal varlıklara inanmayı ve tapınmayı sistemleştiren toplumsal bir kurum” olarak tanımlanır ("Din”, t.y.). 
Her üç kavramın kendine has özellikler barındırmakla birlikte tarihsel süreç boyunca birbirlerinin alanına girdiği, birbirlerini etki altına aldığı görülmektedir. Özellikle sanat ve din yapıları itibariyle siyasetten ayrılsalar da niteliksel açıdan siyaset, bu iki olguyu kontrol etme çabası gütmüştür. Sanat hep bağımsız olduğunu ifade etmek istese de siyaset ve din, vizyon ve misyonlarını aktarmak amacıyla sanatla olan bağlarını sürekli diri tutmuştur.

$\mathrm{Bu}$ üç disiplin arasındaki ilişkiyi tarih, sanat tarihi ve görsel kaynaklarından öğrenmekteyiz. Sanat tarihinin yazınsal sürecini erken dönemde başlatan Avrupa kültürü, kendinden olmayan kültürlere, coğrafyalara kavram, sınıflandırma ve bilgi anlamında siyasi müdahaleler katarak kendi istediği bakış açısını yerleştirmiştir.

Artun'un (2013) açıklamasından da anlaşılır ki 16. yy 'da Giorgio Vasari’nin "Sanatçıların Hayat Hikâyeleri” ile başlayan sanat tarihi yazma süreci, Winckelmann'ın 1764'de yayınladığı ve sanatı toplumsal-politik-kültürel ilişkileriyle ele aldığı “Antik Dönem Sanatı” tarihi ile sanat tarihinin bilimsel çizgiye kavuşması sağlanır.

Sınıflandırma olarak sanat: plastik sanatlar, fonetik sanatlar, ritmik sanatlar gibi klasik ayrımlarla tanımlanmaya çalışılmıştır. Bilim alanı evrimini tamamladıkça sanat tarihi de bu sınıflandırmalarını zenginleşerek çağ, kıta, din, dil, dönem ve kültürel zenginliklere göre alt sınıflandırmalarını yapmıştır.

Siyaset ve ideoloji ekseninde sanat, devletlerin ya da yöneticilerin hem iç politikada hem de diş politikalarda kendi fikirlerini anlatmak, yaymak ve kabul ettirmek amacıyla en etkili şekilde kullanmaya çalıştıkları Nazi Almanyası'ndan, Mussolini İtalyası'ndan ya da Sovyet Rusyası'ndan bilinmektedir. Oryantalizm, Avrupa merkezci anlayışla, sanatın kalıcı etkisinden yararlanmak amacıyla kendisinden olmayan kültürlere dayattığı ve kabul ettirdiği, eylemlerini daha etkili biçime ulaştırmak için tercih ettiği bir kültür sanat deformasyonu dilidir. Oryantalistlerin oluşturduğu auradan kurtulamayan coğrafyalar ise kültürel emperyalizme maruz kalmışlardır.

Asya coğrafyasının kültür ve sanatı incelendiğinde kavramlardan eylemlere emperyalist etki biçim ve içerik olarak hissedilir. Özellikle sanatın dinsel, dilsel ve eylemsel kapsamında kendisini gösteren bu etki, kültürler için sanatını doğru konumlandıramama ve konumlandıramadığı için de gelişim gösterememelerine neden olmaktadır.

Din, bir kültür olarak varlığını sanat tarihinde gösterse de sanat tarihinin barındırdığı kavramlar içinde "Din sanatı" kavramının doğru bir şekilde tanımlanmaması, din ile sanat kavramlarının birlikte anılıp siyasal malzeme haline gelmesi problem olarak görülmektedir.

Din ve sanatın tarihsel süreçlerde birbirlerinin alanına girdikleri ve birbirlerinin alanlarını işgal ettikçe de içinden çıkılmaz sorunlara, kültürel ve toplumsal kargaşalara neden olduğu açıktır.

Konumuz her ne kadar Oryantalizmin İslam Coğrafyası üzerindeki sanat kavramlarına dönük gibi görülse de ilahi dinler olarak kabul edilen Hristiyanlık ve Museviliği de içine alır. Problemin sadece İslam Sanatını kapsamadığı, ilahi olarak kabul edilen bu üç dinin inananlarının aynı problemler üzerinde durduğu ve tartıştığı anlaşılmaktadır.

\section{Yöntem}

Araştırma betimsel modele dayalı nitel bir araştırma olarak yürütülmüştür. Bu kapsamda Oryantalizmin sanat terimleri üzerinden İslam Coğrafyası üzerine etkisi incelenerek, sanatta dine dayandırılan kavram problemleri olarak "İslam Sanatı" (din sanatı) kavramı dini boyutu, sanat boyutu ve siyasi boyutu olmak üzere üç başlık altında incelenmiştir.

\section{Din Sanatı Kavramının Dini, Sanat ve Siyasi Boyutu}

\subsection{Din Sanatı Kavramının Dini Boyutu}

Din; "akıl sahibi insanların kendi istekleri ile dünya ve ahirette iyiliğe ve mutluluğa ulaştırmak amacıyla Allah tarafından peygamberleri aracılığı ile gönderilen esaslar bütünüdür.” ("Din Görevlileri”, 2018) Bir başka tanıma göre "Din; insanların yaratıcılarına olan imanlarını, ona yapacakları ibadetlerin bütününü ve bu imana göre davranışlarının nasıl olması gerektiğini düzenleyen inanış yoludur. Allah ile kul arasındaki irtibattır. İnsanın kişisel ve toplumsal hayatını düzenleyen Cenab-1 Hakk’ın ilahi kanunlarıdır" ("Din”, 2018). Bu ilahi kanunları içinde barındıran İncil, Tevrat ve Kur'an, dünyanın birçok nüfusunun inandığı üç kutsal kitaptır.

Sanat ve din tanımlarına bakıldığında; kendine özgü kuralları olan her iki olgunun da dünyayı daha kaliteli bir yer haline getirmek amacıyla var oldukları açıktır. Ancak sanatın kul yapımı bir eylem, dinlerin ise bir tanrı buyruğu olması birbirlerinden ayrıldıkları en dikkate değer olgudur.

İlahi dinler olarak kabul edilen Musevilik, Hristiyanlık ve İslam'da “sanat yapın” gibi bir emir bulunmamaktadır. Her üç dinin din-sanat ekseninde tartışma biçimleri aynıdır. Özellikle Hristiyanlıkta ikona, ikonofil, ikonoklazma ekseninde olurken, İslam'da sanat-suret yasağı kapsamında zayıf olduğu düşünülen ve aralarında çelişkiler bulunan tartışmalı hadisler çerçevesinde dönmektedir.

Musevilikte on emrin ikincisinde "Kendine yukarıda gökyüzünde, aşağıda yeryüzünde ya da yer altındaki sularda yaşayan herhangi bir canlıya benzer put yapmayacaksın. Putların önünde eğilmeyecek, onlara tapmayacaksın." 
(Besalel, 2011) emri vardır. Putun ne olduğu veya neleri kapsadığı konusunda İbrahim’i dinlerin bir hassasiyetinin olduğu bir gerçektir. Sanat tarihinde dinsel sanat konusunda yerleşik olarak kabul gören ve tarihsel süreçte Hristiyanlık tarihinde olup olmaması tartışılan imge "ikonalar"dır.

Roma imparatorluğu döneminde özelikle 2.yy.'da Hristiyanlar, diğer din ve milletlerin çok tanrılı geleneklerine karşı çıkmış, onları bu tavırları nedeniyle ateist, hatta putperest olarak adlandırarak tanrıların resimlerinin yapılmasını aptalca karşılamıșlardır. Ancak, 3. yüzyıldan sonra Hristiyan kültüründe figüratif çalıșmaların başladığ1 4. yüzyıldan sonra imgelerin ibadetlerde kullanılmasının sıklaştı̆̆ ve özellikle 8. yüzyılda ikonoklazma hareketleri ile dini imgelerin kaldırılma istekleri işlenmiştir. 8. ve 9. yüzyıllarda tartışma devam etmiş; mezhep, dönem ve farklı yerlerde zaman zaman kaldırılan dini imgelerin müşriklerde olduğu gibi tapınma öğesi olarak değil, orijinaline yani imgesi yapılana karşı bir kutsiyet atfetme şeklinde olduğu kabul edilmiştir (Yılmaz, 2017, s. 60-68). Bu bakış açıları Hristiyanlık içindeki mezhep ve bölgelere göre tartışılmaya devam etmektedir.

Yılmaz'ın (2017, s. 33) aktarımıyla; Belting'e göre ikonlar, “önünde ibadet edilen ve hatta önünde ibadet amacıyla mum yakılan" imgeler olarak kabul edilmektedir. İkon, ikonoklazma, ikonofil kavramları Hristiyanlıkta özellikle çok tartışılmış bir kavramdır. İkolastlar dini temsil eden imgelere karşı savaş açarken, ikonofiller dinin daha iyi kavranması için dini betimlemelere ihtiyaç olduğunu savunmuştur.

“İslam Sanat Tarihi ortaya çıkış itibariyle ne İslam’la ne de Müslümanların ürettiği sanatla alakalıdır; o Avrupa'nın kendi kendisini evrensel bir proje olarak kurmasıyla alakalıdır" (Yılmaz, 2017, s. 120). Diğer bir değişle bir disiplin olarak sanat tarihini önceleyen bir "İslam Sanat tarihi” söz konusu değildir. Dolayısıyla İslam sanatı tarihi Batı geleneği ve normlarına göre şekil almıştır.

İslam Sanatı kavramı 19. Yüzyıl da oryantalistlerin "Islamic Art" olarak ortaya attığı bir kavram olduğu bilinmektedir. Bu kelimeler aslında Islamic yani İslam'dan kaynaklanan, referans alan, beslenen bir terimdir ve Türkçe çevirisinde İslam Sanatı olarak kullanılmaya başlamıştır. Oysa yabancı yazarların birçoğunun Islamic Arts olarak kullanmayı tercih ettikleri görülmektedir. İki kullanım arasında çok fark yok gibi görünse de Islamic Art'ta din sanata kaynaklık ederken, İngilizce İslam art ya da Türkçesiyle İslam Sanatı'nda sanatın kendisi tanrının emri ya da onun gönderdiği bir kanun, ayet gibi algılanmaktadır.

İslam kitabı Kur'an-1 Kerim'de ne sanat lehinde önerme ne de aleyhinde bir yasaklama bulunmamaktadır. Buna karşılık Hz. Muhammed'e atfedilen bazı zayıf ve çelişkili olduğu düşünülen hadisler vardır ki; bu hadislerde resim ve heykelin yasak olduğu fikri, tüm İslam dünyasının ve hatta bu konuda araştırma yapan gayrimüslimlerin araştırmalarında yer almıştır. Bu hadislere göre:

1- Hz. Aişe kendi oturduğu evin sofasına üzerinde timsaller bulunan bir perde çekmişti. Hz. Peygamber seferden döndüğünde bunu görünce "Kıyamet gününde en şiddetli azaba çarptırılacak olanlar Allah'ın yaratmasına benzemeye çalışanlardır" buyurdu. Aişe, sonra bu perdeden bir veya iki yastık yaptıklarını söylemiştir ("İslamiyete göre", t.y.).

2- Hz. aişe'nin, üzerinde kuş resmi (timsal) bulunan bir perdesi vardı ve eve girenin ilk önce göreceği bir yere asılmıştı. Hz. Peygamber bunu görünce, "Aişe, şu perdenin yerini değiştir. Eve girip hemen onu görünce dünyayı hatırlıyorum” demiştir ("İslamiyete göre”, t.y.).

3- Hz. Aişe'den rivayet edildiğine göre, Aişe bir defasında üzerinde (hayvan) resimleri bulunan bir minder almıştı. Hz. Peygamber bunu görünce kapının önünde bekledi ve içeri girmedi. Hz. aişe, Resûl-i Ekrem'in yüzünde hoşnutsuzluk işaretlerini görünce, "Ya Resûlallah! Allah'tan ve Allah'ın Resulü'nden bağışlanma dilerim. Bir kusur mu işledim?" dedi. Hz. Peygamber, üzerinde resim bulunan minderi göstererek "Şu minderin burada işi ne?" buyurdu. Aişe "Ya Resûlallah! Onu, kah oturasın, kah yaslanasın diye senin için satın almıştım” dedi. Bunun üzerine Hz. Peygamber, "Bu resimleri yapanlara kıyamet gününde azap edilir ve onlara 'Hadi bakalım, yaptığınız şu sûretlere bir de can verin' denilir. İçinde resimler bulunan eve melekler girmez" ("İslamiyete göre", t.y.).

Yukarıda görülen hadisler de aynı konunun farklı farklı değerlendirildiği görülmektedir. Birinci hadiste resimli perdeden bir ya da iki yastık yaparak kullanıldığı söylenirken, ikinci hadiste ise perdenin yeri değiştirilmiştir. Üçüncü hadiste ise peygamber içeri girdiğinde karşılaştı̆̆ı resimli nesne minderdir ve o minderin oradan ne işi var olduğunu sorgulamıştır ki bu bir çelişkidir. Bu hadislerde melek olan yere meleklerin girmeyeceği söyleniyor. Peki madem resim olan yere melek girmezse birinci ve ikinci hadiste olan hadislerde geçen resimli minderler neden ve nasıl kabul edilmiştir.? Resim minder ya da yastığa dönüşünce melekler o imgeleri resim olarak kabul etmekten vaz mı geçmişlerdir? İslam'da yasak olan canlı cansız bütün tapınma nesneleri için geçerlidir.

Kuran-1 kerim baştan sona okunduğunda resim yapmanın İslami anlamda suç olduğuna dair hiçbir bilgi olmadığ için Kuran-1 anlatıp yaşamakla görevli olan bir peygamberin Kuran a uyumsuz bir söz söylemesi mümkün değildir. Dolayısıyla bunların peygamberin ağzından çıkan bir söz olma ihtimali yoktur. Hadislerin toplanması peygamberin ölümünden iki yüz sene sonra başladığı bilinmektedir. Hadisleri aktaranların okur yazarlık durumları 
da dikkate alınarak dikkat etmelidir. Peygamberin Kuran-1 onaylamayacağı, kuran da yer almayan bir yasak getirme yetkisi bulunmadığı Kuran-a göre yoktur. Helal ve yasak yetkisi Allah a bu yasakların bildirme ve tarif etme yetkisi peygamberlere aittir.

Mesela Kıyamet günü en şiddetli azaba uğrayacak olan ressamlardır. (Buhari Tesavir 89) Oysa büyük büyük günahların derlendiği hiçbir kitapta en şiddetli cezaya uğrayacak listelerinde bu hadislere yer verilmemektedir.

İslam dininin sanat konusunda belirli bir teşviki olmasa da iki kelime ya da kavram bir araya getirilerek sanata kaynaklık eden din, dini göstergelere dönüştüren sanat konusunda da olumsuz bir yargıya varılamaz. "Sanatla İslam kelimelerini bir arada kullanıldığında, kendisini dindar olarak kabul etmeyen kesim, İslam'1 sanata tahammül edemeyecek kadar "geri” görmekte, kendisini dindar olarak kabul eden kesim ise sanatın İslam'la bağdaşmayacak kadar "kötü” ve lüzumsuz olduğunu düşünmektedir” (Çam, 2016, s. 13). Bu durum kutsalı içeren dinlerin tanım ve içeriklerden yola çıkılarak soyut varlık ya da düşüncelerin somut göstergelere dönüştürülemeyeceği veya somutlaştırılan imgenin kutsalın karşılığı olamayacağı düşüncesini ortaya koyar ki iki tinsel durumun karşılaştırılarak zıtlaştırılması anlamsızdır.

"Sanat tarihçileri "kutsal" terimini dini konusu olan herhangi bir eser hakkında kullandıklarında, sanatın esasen "biçim" olduğunu görmezden gelmektedirler. Oysaki sanat, sırf konularının kaynağını manevi hakikatlere dayandırdığı için "kutsal" olarak nitelendirilemez; onun biçimsel dili de aynı kaynaktan neşet etmelidir." (Burckhardt, 2017, s. 7). Yani kaynağı din kitapları olmalıdır. Kutsal olan, kutsal kitaplardaki emirlerin içeriğinin yaşamlara yansımasıdır. Sanat, bir estetik unsur olarak kutsala göndermelerde bulunan bir biçim olarak yerini alırken kutsallığı ön planda olan bir nesne olduğunu iddia etmez. Nesnenin dünyeviliği, iç dünyanın tinsel etkisi özünde kutsal olanı kapsama konusundaki ilahilik kavramı dışında kalarak varlık nedenindeki sınırları aşmaz.

Dinlerde kutsal olarak kabul edilen emirler kutsal kitaplardadır. Dinde kutsallığı ilahi olarak kabul edilmemiş nitelikteki şeylere dini terimleri ekleyenlere Nahl 16'da şöyle geçer: "Dilleriniz yalana alışageldiğinden dolayı, Allah'a karşı yalan uydurmak için, "Şu helâldir", "Şu haramdır” demeyin" ("Nahl”, 2018). Bu ayettten hareketle Kur'an'ın kutsal ya da yasak olarak görmediği sanat için yapılacak bir yorum, dini açıdan problem olarak kabul edilebilir. Ayrıca dinin anlatımı için sembollere ihtiyacı yoktur.

Nisa 50'de "Bak, nasıl Allah'a karşı yalan uyduruyorlar! Hâlbuki apaçık bir günah olarak bu (onlara) yeter!." denilmektedir ("Nisa", t.y.). Dolayısıyla sanatı kutsama adına kutsi olmayan bir şeyi kutsal olarak kabul edip ikonlaştırmak hem sanatın hem de dinin kurallarını öznelliğinden yoksun bırakmaktan başka bir şey değildir.

“İslam Sanatı, Müslümanlar yarattı̆̆ı için değil, İslam vahyinden neş’et ettiğinden dolayı İslam sanatıdır." (Nasr, 2017, s. 16). Bu bakış açısı İslami açıdan Nahl 16'ya göre tehlike arz etmektedir. Sanatçı dini anlamda bir ruhban değildir. Sanatçının dini bir özelliğinin olması ya da eserin din kaynaklı olması; ortaya çıkan eserin kutsal olarak tanımlamasını gerektirmeyeceği gibi bunu vahiy ile açıklamak sanatçıya peygamberlik payesi vermek anlamına gelir.

Burckhardt' a (2017, s. 12) göre ise "sanatçı bilir ki kendisini sanatçının eseri aracılığıyla ifade eden Tanrıdır." Bu bakış açısı insanın iradesini ve sorumluluklarını yok sayma açısından tehlikeli bir durumdur. Çünkü bu sadece sanatçı için değil bütün dünyevi eylemler için geçerli bir durum olarak iyilik ve kötülüğün sorumluluğunu reddeden kaderci anlayıştır.

Sanatta tema olarak birçok imgeden yararlanan sanatçı; özümsediği, belleğinde yer eden ve düşünce boyutunda harmanladığı bir imgeyi sanat diline göre dışa vururken ontolojik bir mantık içinde sınırsız deneyimler yaşar. Bu deneyim veya materyaller ister kültürel, ister dini, ister ekonomik her imgenin dişavurumunda, tinsel derinliği ölçeğinde biçim ve içerik ilişkisine dayalı olarak sanatsal olarak anlamlandırılır.

Bu konunun içeriğine göre dini imgeler kullanılan bir sanat eserinin dinsel olarak adlandırılma zorunluluğu yoktur. Sanatçı dini imgeleri tema olarak seçebilir ve etkileşimini dinden alması, onun din sanatı yaptığı anlamını getirmez. Bir ressam resim türleri olarak manzara, natürmort, figür, portre, soyut, iç mekân ya da janr türünü ana çerçeve olarak kullanır. Peyzaj resmine hiçbir zaman coğrafya sanatı denmediği gibi, teması hukuk olan bir esere de asla hukuk sanatı denmemiştir. Buna bakış acısına göre sanatçının üzerinde çalıştığı her konunun o esere tema olarak verilmesi ya da tema olarak dinlere bağlanması tezat bir durum ortaya çıkarmaktadır.

Sanatçının dini görüşü veya salt din kimliği sanatçının yaptığı eserlerin din sanatı olarak nitelendirilmesini gerektirmeyeceği gibi, sadece sanatçı kimliği ya da o kültüre ait diye dini sanat olarak nitelendirilmesi sanata din zırhı giydirmek veya dinselleştirmektir.

Sanat, tinsel bir dışavurum olmasına rağmen dünyevidir. "Bir kültürel alan olarak bütün sanatlar dinidir. Dolayısıyla topyekün sanat aktivitesi, içerik, form ve tarzı ister profan olsun, ister başka türlü olsun, son noktada dini bir aktivite olmaktadır" (Tokat, 2016, s. 13) derken sanatın dini olan ve olmayan diye ayrımının yersizliğinden bahsettikten sonra din sanatından kastin dini formlar olarak tinselliği kastedilir. 
Eroğlu'nun, İslam Sanatı kitabında “İslam uygarlığının yol açtığı ve İslam Sanatı'nı olası kılan değişikliklerin belirlenmesi, 'Müslüman kullanıcının ve izleyicinin zihin yapısı; sanatçının yaratılana verdiği anlamlar' ve sanatçının kullandığı formlar (aktaran Yılmaz, 2017, s. 37-39) olarak Grabar'dan naklettiği sınıflandırma tartışmaya açıktır. Dini öğeler taşıdığı için İncil'den ilham alınarak yapılan Batı sanatının dinsel imgeleri "Hristiyanlık Sanatı" gibi gösterilmesi sanat tarihinde olmaması gereken bir değerlendirme biçimidir.

\subsection{Din Sanatı Kavramının Sanat Boyutu}

Gotik Sanat dinsel niteliği çok ön planda olan bir dönem olmasına Hristiyanlık Sanatı ismini almamıștır. Dini hassasiyetin ön planda konu edinmesine rağmen sanatsal nitelik üst seviyede bir tinsellik barındırmaktadır. Eserler incelendiğinde dinin yüceliği değil de sanatın nicelik ve niteliği konuşulur. Sanat eserleri şekillendirilirken kaynağın din olması sanatın ve sanatın niteliğinin önüne geçmediği görülür.

Sanat, insanın kendisine karşın yarattığı ikinci bir doğadır; her şeyden önce insanın var olana bir karşı çıkışı, varlığa bir meydan okumasıdır. Başka türlü değişle sanat, insanın gerçekliği aşması ya da kendine özgü başka bir gerçeklik yaratmasıdır. Düşle gerçek arasında kurulan bir köprü olarak sanatsal etkinlik, ussal ile usdışı, düşlem ile gerçek, imgeler ile nesneler arasında bir bağ kurma eylemidir. Kısaca sanat, insanın kendisini tanımasının, dönüştürmesinin ve yaratmasının bir dışavurumu ya da bir serüvenidir (Bozkurt, 2004, s. 11).

Buna göre sanatçı ruhsal şekillenme neticesi ve yaşam sürelerinde edindiği tecrübelerle, hayata bakış açıları, algıları ve düşünme becerileriyle özgür ve özgün bir şekilde eser ortaya koyan, yeni bir söz söyleyen kişidir. "Sanatçı, duyuların katılımıyla imgeleri düşüncede oluşturur. Bu oluşum süreci psikolojik bir süreçtir ve yansıtma biçimi kişiye özgüdür. Düşüncede gelişen imgeyi çeşitli aletlerle yüzeye aktarır. Her aletin resim yüzeyinde yaşayan kendine ait bir hâkimiyeti olduğundan sanatçının da kendine ait verileri, şekillere ve imgelere dönüştüren bir stili oluşmuştur. Sonuçta oluşturulan şekiller, imgeler kendisini görmek istediği şeylerdir” (Kara, 2011, s. 2). Resim, heykel, hat, tezhip, minyatür sanatçısı eser yaratım aşamasında düşünce potasında yoğurduğu kompozisyonlarını bir "özne” olarak ortaya koyar. Temsil noktasında imzasını atıp sanat alımlayıcısının karşısına çıkardığı nesne sanatsal bir nesnedir. Kendine has bakış açıları, görme biçimleri ve yansıtma biçimleri ile diğer öznelerden farkını ortaya koyan bu bakış açısı ve eylem sonucunu görmezden gelerek dinsel bir metin olarak gösterme çabaları, sanatçıya karşı gösterilen bir yok sayma eylemidir.

Özger’e (2013, s. 315) göre İslam, resmi yasakladığı için Müslüman sanatçı ya hüsnühata yönelir ya da minyatüre. Minyatürde perspektif olmadığ 1 gibi ondaki varlıklar gerçek renginin dışındaki renklere boyanır. Kişinin bakışına göre değişen 1şık-gölge, perspektif gibi teknik unsurlar yoktur, âdeta Tanrısal bir bakış söz konusudur. Oysa Doğu toplumları resim yasak olduğu için değil, kendine has bir sanatı, bir tercihi olduğu için minyatür, tezhip ya da hat sanatıyla ilgilidir. Uygurlar Müslüman değillerdi ve Türk minyatürünün kaynağı durumundadırlar. Minyatürde perspektifin olmadığını ifade eden cümleler, perspektifin ne olduğunu bilmemektir. Tanrısal bakış açısı var demek bütün perspektif çeşitlerini en zengin haliyle kabul etmektir. "Minyatür sanatında uzaklık ve boy, renk veya gölgelerle belirtilmez; minyatürler 1şık, gölge, duygu olmayan resimlerdir" ("Minyatür”, t.y.) gibi ifadelere birçok kaynakta denk gelmek mümkündür. Minyatürde ışı gölge olmamasının İslam’da resim yasağından kaynaklandığı belirtilmektedir. Oysa ışık, gölgeye atfedilen bir yasak Kur'an'a dayanmadığı gibi hadislere de dayanmamaktadır. Renkler kültürel tercihler olarak görecelik arz eder ve bu tercihleri dini bir niteliğe dönüştürmek hem din hem de sanatsal ahlaka zıtlık gösterir. Minyatürde kullanılan bu özellikler, Bizans ikonalarında da görülmektedir. Dolayısıyla bu özellikler dini değil kültürel ve coğrafidir. İslam Sanatları olarak adlandırılan tezhip, minyatür hat vb. gibi sanatların kendine has kimlikleri ve sanatsal nitelikleri inkâr edilmemektedir. Hatta Türk-İslam düşüncesindeki bir sanatçının soyut biçimlere geçmesi, onların ruhsal gelişimini göstermesi açısından değerlidir. Tartışmaları bu bağlamda yapmak, bu sanatları kendi alanına hapsederek sanat tanımı ve sınıflandırması dışında tutarak bağlamından çıkarmak oryantalistlerin bakış açılarına hizmet eder.

Doğu sanatçılarının dış doğa ile yetinip sanatlarını şekillendirilmesi ya da iç doğaya dönük eserler vermesi, bu sanatçıların iç dünyaları ile ilintiledikleri bir derinlik algılaması ve bu tinsel derinliğin sanatsal bir dille dışavurumudur. Sanatçılara din sanatçısı ya da eserlerine dini sanat nitelendirilmesinin yapıştırılması onların bağımsız yargılarını yok etme hedefi yanında tasnif dışı bir alana sürükler.

Sanat kendine nesne olarak soyut ve somut her imgeyi kullanır ve özgürlüğünden de asla taviz vermez. Sanat aklı temsil ederken; din, vahyi temsil eder. Sanatçının ilham ve düşünce sistemi, vahiy sistemi olmadığından dolayı yaptıkları dini anlamda kutsal değildir. Sanatın dini, sanat eserindeki dil, bicim ve içeriğinin derinliği nispetinde, sanat alımlayıcılarında bıraktığı tinsel etkidir.

Sanatçı, yaratıcıya muhtaç bir yaratıcı olduğundan dolayı tanrı değildir. Oysa tanrı her şeyi yaratan ama yaratıcıya ihtiyaç duymadığı için en büyük yaratıcıdır. Bu sebeple iki yaratıcı arasındaki farkı tartışmak gereksizdir. Çünkü yaratıcıya muhtaç hiçbir sanatçı en büyük yaratıcı olduğunu iddia etmez. 


\subsection{Din Sanatı Kavramının Siyasi Boyutu}

Kutsal sanat tanımı ikonoklazm, ikonofil ve anikon kavramları içerisinde tartışılmaya başlamasıyla ortaya çıkan sonuçlar üzerinden Avrupa merkezcilik kapsamında geliştirilen Oryantalizm çerçevesinde değerlendirilecektir.

Sanatta oryantalizm üzerine bir sunum yapan Germaner (Gökgöz, 2012), Oryantalizmin sanat tarihinde sadece bir konu olduğunu ifade etmiştir. Oryantalizmi salt bir sanatsal konu üzerinden açıklamak Oryantalizmi hafife almaktır.

Oryantalizm, yalnız kültür, bilimsel faaliyet, yahut müesseselerde pasif bir yansıması olan bir siyasi konu yahut saha değildir. Oryantalizm Doğu hakkındaki sayısız ve lâf kumkuması metinler koleksiyonu da değildir. "Batı" emperyalistlerinin, "Doğu" dünyasını avuç içinde tutmak için başvurdukları alçakça bir planın ismi de değildir. Oryantalizm daha ziyade "jeopolitik bilincin" estetik, akademik, iktisadi, sosyolojik, tarihi ve filolojik metinler arasında dağılımıdır, -sadece Dünya Doğu ve Batı diye birbirine eşit olmayan iki parçadan oluşmuştur diyeni temel bir coğrafi ayırımın değil, bilimsel keşif, filolojik restorasyon, psikolojik tahlil, coğrafi görünüm ve sosyolojik tasvir yolu ile "yaratıp" muhafaza da ettiği bir dizi "menfaatin" ayrıntılı ifadesidir...Oryantalizm'e emperyalizm, pozitivizm, ütopicilik, tarihçilik, Darwinizm, ırkçılık, Freudculuk, Marksizm ve Spenglerizm karışmıştır. Fakat Şarkiyat'ın, diğer doğal ve sosyal bilimler gibi, araştırma ölçüleri, cemiyetleri ve kendi kurumu olmuştur (Said, 1989, s. 18-36).

Terbiye edici, yönetici ve sınıflandırarak "biz ve öteki” şeklinde kümelendirilip ayrıştırıcı nitelikler ortaya koyan bu anlayış, Doğu- Batı ayrımıyla önceleri semitik ayrımla Yahudilik ve İslam'ı, Yahudilerin kendilerini bu durumdan kurtarmasıyla İslam'ı ve Doğu coğrafyasını ele almıştır. Oryantalizm bütün disiplinler üzerinde çalışırken sanatın bütün disiplinlerini silah olarak kullanmışlardır. Osmanlı coğrafyasında henüz şekillenmemiş bazı bilimsel disiplinlerin tanımlanması ve kurulmasında söz sahibi olmak için hem kuramsal hem eylemsel pratiklerde bulunulmuştur. Cumhuriyet dönemi de dâhil olmak üzere Oryantalist anlayışa uygun olarak üretilen eserler, Avrupalılar tarafından desteklenmiştir. Batılıların Islamic Art olarak nitelendirip küçümsedikleri öğeleri tartışırken önce kaynak olarak İslam sanatının Bizans, Helenistik ya da Hristiyan sanatından etkilendiğini tartışmış; kaynakları inceledikçe sınıflandırmayı Oryantalist mantıkla çözümleme yoluna gitmişlerdir. Bu bağlamda İslam Sanatı “Ettinghausen ve İpşiroğlu'na göre Platondan, T, W. Arnold'a göre Hellenistik-Bizans'tan ve Sasani'lerden gelmiştir. İnal'a göre Greko-Budist, Yurtaydın'a göre ise Orta Asya Türk etkileri ve geleneğinde ortaya konmuş eserlerdir" (Sivrioğlu, 2013, s. 1-26). Yabancı bilim adamlarının çoğunluğu Türklerin kendine has bir sanatının olmadığını ve eğer yapmışlarsa da başka kültürlerin etkisinde eserler ortaya koyduklarını ifade ederek yorumlamışlardır.

Kültürler bir toplumun dünyayı algılama şeklini gösteren, yaşanan yerde tapu özelliğini ortaya koyan sözlü, görsel somut-soyut değerler olarak sanatı oluştururlar. Türklerin Orta Asya'da ki kültürünü Budistlere, Anadolu'daki yaşamını Hellenistik, Sasani ya da Bizans’a Arap kültürüne bağlamak planlı bir politikadır. Kültürlerarası iletişim ve etkileşimin olmadığını varsaymak, ne kadar geçersiz bir durum ise, kendine has çizgileri, bakış açıları ve belgeli eserleri olan bir milleti yok saymak, asimilasyonun bilinçli olduğunu gösterir. İslam’ı kabul etmiş toplulukları tek çatı altında görüp millet ayrımı yapmaksızın sanatsal üretimlerini kültürel temelde bir görüp yargılanmalarda bulunmak etik değerlerle bağdaşmaz.

Doğu toplumunda pratikte ortaya konan biçim ve içeriği zengin sanatların kuramsal olarak beslenip belgelendirilmemesi sonucunda, Oryantalistler bu eserleri önce keşfetmiş, sonra tanımlamamış, sonra da bu eserler üzerinden yargılamalarda bulunarak istedikleri yönlendirmeyi hak bilmişlerdir.

Tarihsel olarak düşman kabul edilen Müslümanlar, Hristiyanlarca kafir olarak nitelendirilirken; özellikle 8. yüzyılda yaşanan ikonoklast dönemdeki Hristiyanlık ve resim imgeleri yasağı kapsamında ortaya çıkan mezhepsel tartışmaların cezası İslam'a kesilmiştir. Kendi dinsel problemlerinin dine bakış açılarından kaynaklandığını açıklamak yerine suçlu olarak bu olaylara sebep olduğunu düşündükleri İslam'a ve Müslümanlara yüklemeyi tercih etmişlerdir.

Protestanların, özellikle Luthercilerin Katolikler tarafından Müslümanlara benzetilmesi, ibadethanede dini imge bulundurmaya karşı çıkmalarından dolayı Muhammedî olarak adlandırılmıştır. Bu iddiayı seslendiren Katolikler, Protestanları Türk'e benzetmiş, bu benzerliğe Calvinoturcismus adı verilerek "Barbar Türk imajı" Protestanlarla eşleştirmeye çalışılmıştır. Osmanlının yükseliş döneminde gerileyen Batı’nın, kendi içindeki birliğini bozan Vatikan'ın Hristiyan dünyasındaki mutlak hakimiyetini sarsan Protestanların Müslüman ya da Türk diyerek düşmanlaştırması Protestanların ikonoklazma hareketlerini de Türklere benzetmesi bu nedenle oldukça siyasidir. Batı'da ikonoklazma kelimesi ile Müslümanlığın ya da İslam'ın beraber kullanılması da ilk defa bu dönemde, yani 16. Yüzyılda ortaya çıkmıştır (Yılmaz, 2017, s. 69-70).

Önceleri kendilerinden olmayan Doğu toplumları nezdinde İslam'ı imge düşmanı gibi gösterme çabaları evrilerek Doğu toplumunun küçük düşürülmesi maksadıyla sanatını içeriksiz, düşünce üretmekten yoksun ve kimliksiz gösterme arzusuyla enstitüler kurulup yayınlar yapılmıştır. Bu tutum ve anlayış doğu toplumlarında karşılıksız 
kalmamıştır. Özellikle Türk sanatında mimaride klasik Osmanlı mimarisi bir kenara bırakılarak Barok, Rokoko sanatının etkileri yaygınlaşmıştır. Yabancı hocaların sanat eğitimi ve sanat tarihi derslerine girmesiyle devam eden; resim ve sanat tarihi öğrenmek amaciyla Avrupa'ya gönderilen öğrencilerin orada öğrendiklerini taşıyarak eğitimci olarak yerleştirmesiyle hem dış hem de iç oryantalist etkili sonuçlar ortaya çıkmıştır.

\section{Sonuç}

Başta tanımlamalar olmak üzere temellendirilmesi gereken ve üzerinde düşünülüp tartışılması gereken birçok meselenin olduğu açıktır isim konusunda "Suud Kemal Yetkin İslam Sanatı kavramı yerine tercih ettiği İslam ülkelerinde sanat ya da devletlerinde sanat deyimi oldukça sağlıklı bir tanımlama olarak görülmektedir" der. (Gün ve Can, 2017, s. 13). İslam sanatı olarak nitelendirilen disiplinlerden her birinin kendine has özellikleri ve isimleri bulunmaktadır. Dini bir kavram eklentisi yapmaksızın milliyete göre Türk Sanatı ya da Türk Tezhip Sanatı mantığında kullanılması genel bir coğrafyanın din kisvesi altında toptancı bir anlayışla isimlendirilmesi özgün nitelik ve milliyetlere has özellikleri ortadan kaldırmak için yapılmış bir eylem gibi durmaktadır. Tinsel niteliği ne kadar yüce olursa olsun kul yapımı bir sanatı dinselleştirerek onun kutsallığı üzerinden "İslam Sanatı" kavramı çıkarılamaz. Bu iki kavramın iki ayrı sistem olması bir yana illa yan yana kullanma isteği varsa İslam Sanatı değil "İslamcı sanat "olur ki bu tanım sanatın özünü zedeleyecek bir durumu ortaya çıkarabilir.

Oryantalizmin plan ve projeleri içinde var olan İslam'ın dönüştürülmesi ve İslam'da reform düşüncesi çerçevesinde ırksal, terbiye edici bir iktidar söylemiyle oluşturulan "İslam Sanatı" kavramı idealini Batılıların benimsemesinin yanında Müslümanlar da kendi üzerlerine oynanan post kolonyal düşünceleri bilerek ya da bilmeyerek çoğunlukla kabul edip bir şekilde benimsemiş, Oryantalistlerin sözcüsü olmuşlardır. Bunu yapan Müslümanlar, Doğu ya da İslam'a hizmet ediyormuş ve savunuyormuş gibi bir İslami pozisyon alarak yapmışlardır.

"Din Sanatı" kavramı sanatı sınırladığından dolayı sanatın özgünlüğü ve özgürlüğüyle uyuşmamaktadır. Sanatçının özgünlüğü ve özgürlüğü, ona sınırsız imgelerin açık olması ile yeni bir söz söyleme imkânı sağlar. Bu bağlamda sanatçı belli bir düşüncenin esiri olamaz veya olmamalıdır.

Sanatın dünyeviliği tinsellik açısından estetikle bağdaştırılırken, dinin tinselliği dünyevilikten uzaklaşarak estetikle bağdaştırılır. Din ya da dini içerikleri olan sanat ne kadar sanatsa; sanat da içeriklerinden dolayı o kadar dindir.

İslam Sanatı, İslam Sanatları, Geleneksel Sanatlar kavramları yeniden ele alınmalı ve bütün İslam Coğrafyasını kapsayan bu tanımlamalar yerine özellikle bu tanımlamalar içine giren alanların Tezhip Sanatı, Hat sanatı gibi kendi öznel isimleriyle anılması gerekir. İlla coğrafi olarak ele alınacak ise mutlaka Türk Sanatları üst kimliği altında alanlar tanımlanmalıdır. Kısacası İslam Sanatı kavramı öylesine tanımlamamıştır. Türk sanat tarihçileri de kullanılan bu terimi öylesine kabul etmemeli ve kendi tanımlamasını yapmalıdır.

\section{Kaynakça}

Artun, A. (2013, 10 Eylül). Sanat tarihinin ilk kitabı. E-Skop. Erişim adresi: https://www.eskop.com/skopbulten/sanat-tarihinin-ilk-kitabi/1477/

Besalel, Y. (2011, 27 Nisan). Yahudilikte temel kavramlar. Şalom. Erişim adresi: http://www.salom.com.tr/haber78241-yahudilikte_temel_kavramlar_on_emIr.html

Bozkurt, N. (2004). Sanat ve estetik kuramları. Bursa: Asa Kitapevi.

Burckhardt, T. (2017). Doğu'da Batı'da kutsal aanat. İstanbul: İnsan Yayınlar1.

Çam, N. (2016). İslam'da sanat, sanatta İslam. Ankara: Akçă̆ Yayınları.

Din Görevlileri. (2018, 29 Mart). Din [Blog yazısı]. Erişim adresi: http://dingorevlileri.blogcu.com/diyanet-temeldini-bilgiler/163335

Din nedir?. (2018, 29 Mart). Erişim adresi: https://www.sorusorcevapbul.com/soru-cevap/muhtelif/din-nedir

Din. (t.y.). Türk Dil Kurumu güncel Türkçe sözlük içinde. Erişim adresi: https://sozluk.gov.tr

Eroğlu, Ö. (2016). İslam sanatı. İstanbul: Tekhne Yayınları.

Gökgöz, Z. (2012, 14 Nisan). Sanatta Doğu imgesi. Bilim ve Sanat Vakfi. Erişim adresi: https://bisav.org.tr/Bulten/ 176/1053/sanatta_dogu_imgesi

Gün, R., \& Can, Y. (2017). Ana hatlarıla Türk İslam sanatlarl ve estetiği. İstanbul: Kayıhan Yayınları.

İslamiyete göre fotoğraf ve resimin hükmü nedir?. (.t.y.). Erişim Adresi: https://www.risaleajans.com/sorucevap/islamiyete-gore-fotograf-ve-resimin-hukmu-nedir 
Kara, D. (2011). Sanat yapıtının oluşum süreci. Süleyman Demirel Üniversitesi Güzel Sanatlar Fakültesi ART-E Sanat Dergisi, 4(8), 1-5. Erişim adresi: https://dergipark.org.tr/tr/download/article-file/193358

Minyatür Sanatı. (t.y.). Erişim Adresi: https://www.kulturportali.gov.tr/portal/minyatursanati

Nahl suresi meali. (2018, 4 Nisan). Erişim adresi: http://www.kuranmeali.com/AyetKarsilastirma.php?Sure=16\& ayet $=11604.04 .2018$

Nasr, H. S. (2017). İslam sanatı ve maneviyatı. İstanbul: İnsan Yayınları.

Nisa suresi. (t.y.). Erişim adresi: https://kuran.diyanet.gov.tr/mushaf

Özger, M. (2013). İslam sanatı ve estetiğinde hakikat ve mecaz-iki poetik tavır: Necip Fazıl ve Sezai Karakoç. İslâmî İlimler Dergisi, 8(1), 313-324. Erişim adresi: https://dergipark.org.tr/tr/download/article-file/418636

Said, E. W. (1989). Oryantalizm: Sömürgeciliğin keşif kolu (S. Ayaz, Çev.). İstanbul: Pınar Yayınları.

Sanat. (t.y.). Türk Dil Kurumu Güncel Türkçe Sözlük içinde. Erişim adresi: https://sozluk.gov.tr

Sivrioğlu, U. T. (2013). İslâm kitap resmi ve minyatür sanatında Hellenistik-Bizans etkisi. Akademik Tarih ve Düşünce Dergisi, 1(1), 1-26. Erişim adresi: https://dergipark.org.tr/tr/download/article-file/441482

Siyaset. (t.y.). Türk Dil Kurumu Güncel Türkçe Sözlük içinde. Erişim adresi: https://sozluk.gov.tr

Tokat, L. (2016). Kutsal ve sanat. Din Bilimleri Akademik Araştırma Dergisi, 16(2), 9-22. Erişim adresi: http://isamveri.org/pdfdrg/D03296/2016_2/2016_2_TOKATL.pdf

Vasari, G. (2013). Sanatçıların hayat hikayeleri (E. Gökteke, Çev.). İstanbul: Sel Yayınları.

Yılmaz, N. (2017). İslam'da resim yasă̆ söylemi. İstanbul: Doğan Kitap. 